\title{
ANALISIS PENDAPATAN PETERNAK SAPI POTONG DI KECAMATAN SIEMPAT NEMPU HULU KABUPATEN DAIRI
}

\author{
The Analysis of Farmer Income Beef Cattle in Siempat Nempu Hulu Subdistrict, \\ Dairi Regency \\ Sartika Bancin ${ }^{1}$, Hasnudi ${ }^{2}$ dan Usman Budi ${ }^{2}$ \\ 1. Mahasiswa Program Studi Peternakan Fakultas Pertanian Universitas Sumatera Utara \\ 2. Staff Pengajar Program Studi Peternakan Fakultas Pertanian Universitas Sumatera Utara
}

\begin{abstract}
Beef cattle fattening business the sideline majority of the community in the Siempat Nempu Hulu subdistrict where there are differences in the profile of the community, therefore need to analyze farmer income beef cattle in this subdistricts. This research was conducted in the Siempat Nempu Hulu subdistrict, Dairi district, which began on Juny until September 2013. This study used respondents, who had beef cattle traditional fattening. Samples obtained through proportional stratified random sampling method and retrieved 69 farmers, there was 42 respondens of Gunung Meriah, 21 respondens of Silumboyah and 6 respondens of Sungai Raya. Income data analysis methods using multiple linear regression analysis. The results showed that the scale of business, education level farmer positive effect on increasing revenue beef cattle, while age, experiences and number of dependents negatively affect earnings beef cattle farmers in Siempat Nempu Hulu subdistrict Dairi district.
\end{abstract}

Keywords: Farmer Profile, Income Farmers, Beef Cattle Fattening

\section{ABSTRAK}

Peternakan sapi potong penggemukan merupakan usaha sampingan mayoritas masyarakat di Kecamatan Siempat Nempu Hulu dimana terdapat perbedaan profil dari masyarakat tersebut. Oleh sebab itu perlu diketahui analisis pendapatan peternak sapi potong di kecamatan tersebut. Penelitian ini dilaksanakan di Kecamatan Siempat Nempu Hulu Kabupaten Dairi Propinsi Sumatera Utara mulai bulan Juni sampai September 2013. Penelitian ini menggunakan metode survey dengan unit responden keluarga yang memelihara ternak sapi potong. Sampel diperoleh melalui metode Proportional Stratified Random Sampling dan diperoleh 69 orang peternak, yaitu dari desa Gunung Meriah berjumlah 42 responden, desa Silumboyah berjumlah 21 responden dan desa Sungai Raya berjumlah 6 responden. Metode analisis data pendapatan menggunakan analisis regresi linier berganda. Hasil penelitian menunjukkan bahwa skala usaha, pendidikan peternak berpengaruh positif terhadap pendapatan peternak sapi potong sedangkan umur, pengalaman beternak dan jumlah tanggungan keluarga berpengaruh negatif terhadap pendapatan peternak sapi potong.

Kata Kunci: Profil Peternak, Pendapatan Peternak, Penggemukan Sapi

\section{PENDAHULUAN}

Pembangunan subsektor peter-nakan merupakan bagian dari pembangunan pertanian yang bertujuan untuk mencapai suatu kondisi peternakan yang tangguh, yang dicirikan dengan kemampuan mensejahterakan para petani-ternak dan kemampuannya dalam mendorong pertumbuhan sektor terkait secara keseluruhannya. 
Pembangunan sub sektor peternakan di Indonesia mempunyai tujuan untuk meningkatkan produksi ternak. Peningkatan produksi ini diharapkan akan membawa dampak terhadap peningkatan pendapatan peternak, memperbaiki keadaan lingkungan, meningkatkan kesempatan berusaha, membuka lapangan kerja baru dan memperluas kesempatan kerja yang telah ada. Tujuan jangka panjang pembangunan sub sektor peternakan salah satunya adalah tercapainya standar kecukupan gizi dari hasil ternak bagi masyarakat Indonesia (Sosroamidjojo dan Soeradji, 1990).

Berkaitan dengan hal tersebut, perlu diidentifikasi alternatif pola pengembangan peternakan rakyat yang mempunyai skala usaha yang ekonomis yang mampu memberikan kontribusi terhadap pendapatan keluarga yang cukup memadai. Dalam perspektif ke depan, usaha peternakan rakyat harus mengarah pada pengembangan agribisnis peternakan sehingga tidak hanya sebagai usaha sampingan namun sudah mengarah pada usaha pokok dalam perekonomian keluarga. Dengan kata lain, usaha ternak rakyat diharapkan menjadi sumber utama pendapatan peternak rakyat (paling tidak) dan dapat memberikan kontribusi terhadap pemenuhan kebutuhan keluarga peternak, seperti pada kegiatan ekonomi keluarga lainnya dan bahkan mengarah usaha peternakan keluarga (Widjaja, 1999).

Salah satu kebijakan pemerintah dalam pembangunan sektor peternakan yaitu berupaya untuk mencukupi kebutuhan protein hewani. Pada akhirnya, upaya ini akan berpengaruh terhadap peningkatan kecerdasan bangsa.

Daging sangat besar manfaatnya bagi pemenuhan gizi berupa protein hewani, namun pemenuhan daging belum mencukupi kebutuhan konsumsi yang terus meningkat. Peningkatan produksi daging sangat berhubungan dengan penyebaran populasi ternak pada suatu daerah, lebih mendukung lagi apabila pengolahan ataupun pemeliharaan dilakukan secara modern. Namun pemeliharaan yang dilakukan masih bersifat tradisional (Santoso, 1979).

Ternak sapi khususnya sapi potong merupakan salah satu sumber daya penghasil bahan makanan berupa daging yang memiliki nilai ekenomis tinggi dan penting artinya dalam kehidupan masyarakat dalam pemenuhan protein hewani. Ternak sapi potong selain sebagai penghasil daging dapat juga menghasilkan pupuk kandang, kulit, tulang, dan sebagainya dari hasil ikutannya.

Ada beberapa faktor yang menyebabkan jumlah produksi daging rendah, yaitu populasi dan produksi sapi yang masih rendah khususnya daerah Sumatera Utara. Sumatera Utara memiliki 
beberapa daerah yang sangat padat, sedang dan ada yang sangat jarang atau terbatas penyebaran populasi ternak sapi potong. Hal ini tentu saja mempengaruhi besarnya pendapatan masyarakat pada daerah tersebut sehingga menimbulkan perbedaan dalam segi ekonomi maupun pemenuhan gizi hewani khususnya daging sapi (Azis, 1993).

Usaha sapi potong di Sumatera Utara tersebar di berbagai daerah dengan tingkat kepadatan populasi yang berbeda-beda. Kecamatan Siempat Nempu Hulu merupakan salah satu daerah penyebaran populasi ternak di Kabubaten Dairi dimana kawasan tersebut perkembangan popolasi ternak sapinya pada tahun 2013 mencapai 898 ekor (Dinas Perikanan dan Peternakan Kabupaten Dairi, 2013).

Dalam melakukan usaha ternak sapinya, peternak berperan sebagai pembuat keputusan yang berusaha mengambil keputusan yang efektif dan efisien dalam menjalankan dan mengelola usahanya. Karakteristik sosial ekonomi peternak (skala usaha, jumlah ternak sapi, umur peternak, tingkat pendidikan, pengalaman beternak, jumlah tanggungan keluarga dan motivasi beternak dapat mempengaruhi dalam mengambil keputusan yang dapat memberikan pengaruh keuntungan bagi usahanya. Peternak berusaha untuk mengalokasikan faktor produksi seefisien mungkin (lahan, modal, dan tenaga kerja) untuk memperoleh hasil dan keuntungan maksimal (Fathoni, 2004).

Sehubungan dengan hal tersebut penulis mencoba meneliti dan menganalisis faktor-faktor yang mempengaruhi pendapatan peternak sapi potong pada suatu daerah berdasarkan profil peternak.

\section{BAHAN DAN METODE PENELITIAN}

\section{Tempat dan Waktu Penelitian}

Penelitian ini dilaksanakan di Desa Gunung meriah, Desa Silumboyah dan Desa Sungai Raya Kecamatan Siempat Nempu Hulu, Kabupaten Dairi, Provinsi Sumatera Utara mulai dari 25 Juni sampai dengan 10 September 2013.

\section{Metode Penelitian}

1. Penentuan Responden dan Analisis Pendapatan

Responden terdiri dari para peternak sapi di Kecamatan Siempat Nempu Hulu Kabupaten Dairi. Metode penelitian yang digunakan adalah metode survey dengan unit responden yang memelihara ternak sapi. Metode penarikan responden yang digunakan adalah sebagai berikut : 
- Pada tahap pertama 3 buah desa dari beberapa desa yang ada di Kecamatan Siempat Nempu Hulu dengan penarikan responden secara Proportional Stratified Random Sampling. Soekartawi (1995), yaitu desa yang populasi ternak sapinya tinggi, sedang dan jarang tersebut ditentukan dengan melihat data dari Badan Pusat Statistik Kabupaten Dairi dalam angka 2013 dipilih tiga desa yaitu,

Desa yang kepadatan populasi ternaknya padat adalah Gunung Meriah

Desa yang kepadatan populasi ternaknya sedang adalah Silumboyah

Desa yang kepadatan populasi ternaknya jarang adalah Sungai Raya

- Pada tahap kedua pemilihan responden secara acak sederhana, diambil masing-masing 30\% dari seluruh peternak dari setiap desa sampel. Untuk penelitian yang akan menggunakan data statistik ukuran sampel paling kecil 30\% sudah dapat mewakili populasi (Wirartha, 2006). Dari masing-masing desa di peroleh jumlah peternak yang menjadi sampel sebanyak:

- desa Gunung Meriah 139 orang peternak, maka jumlah sampel 42 0rang peternak

- desa Silumboyah 70 orang peternak, maka jumlah sampel 21 peternak

- desa Sungai Raya 6 orang peternak, maka jumlah sampel 6 peternak

\section{Pengumpulan Data}

Data yang dikumpulkan dalam penelitian ini terdiri dari data primer dan sekunder.

1. Data primer diperoleh dari monitoring terhadap kegiatan usaha ternak sapi potong melalui wawancara dan pengisian daftar kuisioner.

2. Data sekunder diperoleh dari berbagai instansi yang terkait seperti Badan Pusat Statistik Kabupaten Dairi dan kantor kepala desa.

\section{Analisis Data}

Data yang diperoleh dari hasil wawancara di lapangan diolah dan ditabulasi kemudian dibuat rataannya. Kemudian data rataan dimasukkan ke dalam neraca keuangan masing-masing peternak dan diambil rataan pendapatan peternak. Kemudian data tersebut dianalisis dengan menggunakan metode analisis pendapatan dan analisis regresi berganda dengan rumus sebagai berikut :

- Analisis pendapatan

$$
\mathbf{P d}=\mathbf{T R}-\mathbf{T C}
$$


Keterangan :

Pd : adalah total pendapatan atau keuntungan yang diperoleh peternak sapi potong (rupiah/tahun)

TR : adalah total revenue atau penerimaan yang diperoleh peternak sapi potong (rupiah/tahun)

TC : adalah biaya yang dikeluarkan peternak sapi potong (rupiah/tahun).

Jumlah pendapatan ditabulasi secara sederhana, yaitu dengan menghitung pendapatan peternak pada usaha beternak sapi potong terhadap keluarga di daerah penelitian. Berdasarkan hasil yang telah diperoleh, maka untuk melihat faktor-faktor yang mempengaruhi pendapatan dapat dilihat dengan menggunakan model pendekatan teknik Ekonometri dengan menggunakan analisis regresi linear berganda dengan alat bantu software Statistical Package for Sosial Sciences (SPSS 16). Menurut Djalal dan Usman (2002) model pendugaan yang digunakan:

$$
\hat{Y}=a+b_{1} X_{1}+b_{2} X_{2}+b_{3} X_{3}+b_{4} X_{4}+b_{5} X_{5}+\mu
$$

Keterangan:

$\hat{\mathrm{Y}} \quad$ : adalah pendapatan peternak (Y : topi) yang dipengaruhi beberapa faktor dalam memelihara ternak sapi potong

a : adalah koefisien intercept (konstanta)

$\mathrm{b}_{1}, \mathrm{~b}_{2}, \mathrm{~b}_{3} \quad$ : adalah koefisien regresi

$\mathrm{X}_{1} \quad$ : adalah skala usaha/jumlah sapi (ekor)

$\mathrm{X}_{2} \quad$ : adalah umur peternak (tahun)

$\mathrm{X}_{3} \quad$ : adalah tingkat pendidikan (tahun)

$\mathrm{X}_{4} \quad$ : adalah lama beternak (tahun)

$\mathrm{X}_{5} \quad$ : adalah jumlah tanggungan keluarga (jiwa)

$\mu \quad$ : adalah variabel lain yang tidak diteliti

Variabel-variabel pada hipotesis diuji secara serempak dan parsial untuk mengetahui apakah variabel tersebut mempunyai pengaruh dominan atau tidak. Jika variabel tersebut berpengaruh secara serempak maka digunakan uji F yakni:

$$
F=\frac{r^{2} / k}{\left(1-r^{2}\right) /(n-k-1)}
$$

Keterangan:

$\mathrm{r}^{2} \quad=$ Koefisien determinasi

$\mathrm{n} \quad=$ Jumlah responden

$\mathrm{n}-\mathrm{k}-1=$ Derajat bebas penyebut 
Kriteria uji:

F-hit $\leq$ F-tabel - H0 diterima (H1 ditolak)

F-hit $\geq$ F-tabel - H0 ditolak (H1 diterima)

Menurut Sudjana (2002), jika variabel berpengaruh secara parsial dapat diuji dengan uji t yakni:

$$
\text { Thit }=\frac{b_{1}}{S b_{1}}
$$

$$
\mathrm{S}^{2} y_{123}=\frac{\Sigma(\hat{\mathrm{y}}-\mathrm{y})^{2}}{\mathrm{n}-\mathrm{k}-1}
$$

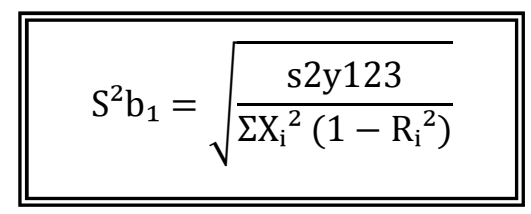

Keterangan:

$$
\begin{array}{ll}
\mathrm{b} & =\text { Parameter }(\mathrm{i}=1,2,3) \\
\mathrm{n}-\mathrm{k}-1 & =\text { derajat bebas } \\
\boldsymbol{S}^{2} & =\text { Standart error parameter } \mathrm{b} \\
\mathrm{S}^{2} y_{123} & =\text { Standart error estimatis } \\
\mathrm{x}_{\mathrm{i}} & =\text { Variabel bebas }(\mathrm{i}=1,2,3)
\end{array}
$$

Kriteria uji:

t-hit $\leq \mathrm{t}$-tabel - H0 diterima (H1 ditolak)

t-hit $\geq \mathrm{t}$-tabel - H0 ditolak (H1 diterima)

Kriteria pengambilan keputusan:

$$
\begin{aligned}
& \text { t-tabel }=(\alpha ; \mathrm{db}) \\
& (\alpha=5 \% ; \mathrm{db}=\mathrm{n}-\mathrm{k}-1)
\end{aligned}
$$

\section{Keterangan:}

$\mathrm{n}=$ jumlah sampel

$\mathrm{k}=$ jumlah variabel bebas $(\mathrm{X})$

a. t-hitung $>$ t-tabel (taraf signifikan $\alpha \leq 0,010$ ) : H0 ditolak, berarti koefisien regresi dari faktor tertentu berpengaruh nyata terhadap variabel terikat.

b. t-hitung $<$ t-tabel (taraf signifikan $\alpha \geq 0,100$ ) : H0 diterima, berarti koefisien regresi dari faktor tertentu berpengaruh tidak nyata terhadap variabel terikat.

\section{Parameter Penelitian}

\section{Analisis Pendapatan}

a. Skala usaha adalah jumlah ternak sapi yang dipelihara peternak (ekor)

b. Umur peternak adalah umur peternak yang memelihara sapi yang diukur berdasarkan usia kerja produktif yaitu 16-60 tahun

c. Tingkat pendidikan adalah lamanya pendidikan formal yang ditempuh peternak (tahun)

d. Pengalaman (lama) beternak adalah lamanya peternak memelihara ternak sapi dan pernah mengikuti pelatihan (tahun) 
e. Jumlah tanggungan keluarga yaitu jumlah tanggungan yang ditanggung peternak dalam satu keluarga (jiwa)

f. Penerimaan adalah jumlah perkalian antara total produksi dengan harga jual (Rp)

g. Pengeluaran adalah semua biaya yang dikeluarkan dalam suatu usaha

h. Pendapatan adalah selisih antara penerimaan dengan pengeluaran selama pemeliharaan ternak sapi dalam kurun waktu tertentu, misalnya 1 (satu) tahun/peternak.

\section{HASIL DAN PEMBAHASAN}

\section{Letak dan Geografi Kecamatan Siempat Nempu Hulu}

Kecamatan Siempat Nempu Hulu berada di ketinggian 700-1.250 meter diatas permukaan laut, luas wilayah 93,93 $\mathrm{Km}^{2}$. Kecamatan Siempat Nempu Hulu sebelah Utara berbatasan dengan Kecamatan Pegagan Hilir dan Tigalingga, sebelah Selatan dengan Siempat Nempu, sebelah Barat dengan Kecamatan Tigalingga dan sebelah Timur dengan Kecamatan Sidikalang. Serta jarak kantor camat ke kantor bupati yaitu $11 \mathrm{Km}$.

\section{Tata Laksana Pemeliharaan Sapi Potong}

Jenis sapi potong yang di pelihara peternak responden 90\% PO (peranakan ongole) dan 10\% jenis sapi lainnya. Pemeliharaan sapi potong di Kecamatan Siempat Nempu Hulu dilakukan dengan cara di gembalakan pada pagi sampai malam hari di padang pengembalaan. Pada siang hari ternaknya diberi minum secara terbatas.

Lokasi kandang ternak umumnya berada di ladang peternak itu sendiri, biasanya ternaknya diikat di bawah pohon rindang sehingga jika saat hujan ataupun panas ternaknya dapat berlindung di bawah pohon tersebut. Pemberian obat cacing diberikan 6 bulan sekali, dengan dosis 1 tablet dalam sekali pemberian, harga 1 tablet obat cacing tersebut yaitu Rp 50.000. Obat cacing yang digunakan adalah Brenkazol, obat cacing tersebut diperoleh dari poultry shop.

\section{Profil Responden}

Karakteristik responden dalam penelitian ini meliputi karakteristik sosial dan ekonomi. Karakteristik sosial peternak yang dianalisis meliputi umur peternak, tingkat pendidikan dan pengalaman beternak. Sedangkan karakteristik ekonomi responden yang dianalisis meliputi: total penerimaan dari usaha ternak, total biaya produksi dan pendapatan bersih usaha. 
Skala usaha peternak sapi didominasi pada jumlah ternak 1 ekor sampai 5 ekor dengan banyaknya peternak 56 orang yaitu $81,15 \%$. Berdasarkan data tersebut dapat dikatakan bahwa jumlah kepemilikan ternak sapi dalam usaha beternak masih sedikit, sementara di daerah penelitian masih cukup luas lahan kosong sebagai tempat penggembalaan ternak sapi dan untuk penanaman hijauan juga masih banyak yang dapat digunakan.

Untuk lebih mengetahui jumlah populasi ternak sapi potong secara rinci dalam Kecamatan Siempat Nempu Hulu dapat dilihat pada Tabel 1 berikut ini.

Tabel 1. Populasi Ternak Sapi Potong di Kecamatan Siempat Nempu Hulu

\begin{tabular}{llcccc}
\hline No & Desa & $\begin{array}{c}\text { Luas Desa } \\
\left(\mathrm{km}^{2}\right)\end{array}$ & $\begin{array}{c}\text { Jumlah sapi } \\
\text { Potong }\end{array}$ & Jumlah KK & $\begin{array}{c}\text { Kepadatan } \\
\text { Sapi/Km }\end{array}$ \\
\hline 1 & Tambahan & 7,13 & 0 & 247 & 0 \\
2 & Kuta Tengah & 12,1 & 0 & 345 & 0 \\
3 & Lae Nuaha & 8 & 0 & 506 & 0 \\
4 & Sungai Raya & 8 & 10 & 531 & 1,25 \\
5 & Gunung Meriah & 8,7 & 321 & 363 & 36,896 \\
6 & Sigambir-gambir & 6,8 & 212 & 240 & 31,176 \\
7 & Silumboyah & 6,2 & 154 & 382 & 24,838 \\
8 & Pangaribuan & 4 & 32 & 273 & 8 \\
9 & Tualang & 9,2 & 57 & 339 & 6,195 \\
10 & Bakal Julu & 6.6 & 69 & 320 & 10,45 \\
11 & Sipoltong & 8 & 12 & 221 & 1,5 \\
12 & Pandan & 9,2 & 31 & 305 & 3,369 \\
\hline
\end{tabular}

Umur peternak dapat di dominasikan pada umur 51 tahun sampai 55 tahun dengan jumlah 15 orang yaitu $21,73 \%$. Bila dikaji dari karakteristik umur di atas, sebagian besar peternak dalam kategori usia yang produktif (16-60 tahun), sehingga potensi untuk bekerja dan mengelola usaha ternaknya masih besar.

Lama pendidikan peternak sapi di dominasikan pada 6 tahun sampai 10 tahun dengan jumlah peternak 50 orang dengan jumlah persen $72,46 \%$. Hal ini menunjukkan bahwa lamanya pendidikan responden umumnya tergolong Sekolah Dasar (SD), sehingga lama pendidikan responden digolongkan rendah. Pendidikan non formal di daerah penelitian yang khusus mengenai usaha ternak sapi tidak berjalan dengan baik. Karakteristik responden di daerah penelitian dapat dilihat pada Tabel 2 berikut: 
Tabel 2. Karakteristik responden di daerah penelitian tahun 2013.

\begin{tabular}{|c|c|c|}
\hline No. Karakteristik peternak sampel & Satuan (orang) & $\%$ \\
\hline \multicolumn{3}{|l|}{ 1. Jumlah ternak/ Skala Usaha (ekor) } \\
\hline $1-5$ & 56 & 81,15 \\
\hline $6-10$ & 8 & 11,59 \\
\hline $11-15$ & 3 & 4,34 \\
\hline $16-20$ & 1 & 1,44 \\
\hline $21-25$ & 1 & 1,44 \\
\hline \multicolumn{3}{|l|}{ 2. Umur peternak (tahun) } \\
\hline $21-25$ & 1 & 1,44 \\
\hline $26-30$ & 2 & 2,89 \\
\hline $31-35$ & 5 & 7,24 \\
\hline $36-40$ & 9 & 13,04 \\
\hline $41-45$ & 9 & 13,04 \\
\hline $46-50$ & 11 & 15,94 \\
\hline $51-55$ & 15 & 21,73 \\
\hline $56-60$ & 10 & 14,49 \\
\hline $61-65$ & 4 & 5,79 \\
\hline $66-70$ & 1 & 1,44 \\
\hline $71-75$ & 2 & 2,89 \\
\hline \multicolumn{3}{|l|}{ 3. Lama pendidikan (tahun) } \\
\hline $6-10$ & 50 & 72,46 \\
\hline $11-15$ & 19 & 27,53 \\
\hline \multicolumn{3}{|l|}{ 4. Lama Beternak (tahun) } \\
\hline $1-5$ & 26 & 37,68 \\
\hline $6-10$ & 34 & 49,27 \\
\hline $11-15$ & 4 & 5,79 \\
\hline $16-20$ & 3 & 4,34 \\
\hline $21-25$ & 1 & 1,44 \\
\hline $26-30$ & 1 & 1,44 \\
\hline \multicolumn{3}{|l|}{ 5. Jumlah tanggungan keluarga (orang) } \\
\hline $0-4$ & 46 & 66,66 \\
\hline $5-9$ & 23 & 33,33 \\
\hline
\end{tabular}


Pengalaman beternak di dominasikan pada 6 tahun sampai 10 tahun dengan banyaknya peternak 34 orang jumlah persen yaitu 49,27\%. Hal ini menunjukkan bahwa tingkat pengalaman beternak responden dapat dikatakan cukup, tetapi kurang menguasai dan mengikuti perkembangan teknologi dalam pengelolaan usaha ternak sapinya.

Jumlah tanggungan keluarga dapat di dominasikan dari 0 orang sampai 4 orang sebanyak 46 orang dengan persen $66,66 \%$. Hal ini menunjukkan bahwa dalam jumlah tanggungan keluarga tersebut dapat dikatakan seimbang dengan in come (pendapatan) dari usaha peternak.

\section{Pendapatan Peternak}

Pada usaha ternak sapi potong di daerah penelitian diperoleh total penerimaan dari usaha ternak sapi selama 1 (satu) tahun adalah berkisar antara Rp 3.000 .000 sampai dengan $\mathrm{Rp}$ 47.500.000/tahun/peternak dengan rataan sebesar $\mathrm{Rp}$ 9.647.826,087/tahun/peternak.

Tabel 3. Penerimaan dan pengeluaran peternak di daerah penelitian tahun 2013

\begin{tabular}{llcc}
\hline $\begin{array}{l}\text { Karakteristik peternak } \\
\text { sampel }\end{array}$ & Satuan & Total & $\%$ \\
\hline Pemasukan & & & \\
- Penjualan Ternak & Rp/tahun & 2.547 .000 .000 & 97,82 \\
- Penjualan Feses & Rp/tahun & 56.600 .000 & 2,17 \\
Biaya pengeluaran & & & \\
- Bibit & Rp/tahun & 1.415 .000 .000 & 73,39 \\
- Obat-obatan & Rp/tahun & 32.400 .000 & 1,68 \\
- Pakan & Rp/tahun & 480.600 .000 & 24,92 \\
B/C Ratio & & 1,35 & \\
\hline
\end{tabular}

Total biaya produksi pada usaha ternak sapi potong meliputi biaya jumlah tanggungan keluarga, biaya obat-obatan dan biaya lainnya. Menurut data yang diperoleh selama 1 tahun dari usaha ternak sapi per responden adalah berkisar antara $\mathrm{Rp} 5.200 .000$ sampai dengan $\mathrm{Rp}$ 164.100.000 dengan nilai pengeluaran rata-rata adalah $\operatorname{Rp} 27.942 .028,99 /$ tahun/peternak.

Pendapatan bersih setiap responden dari usaha ternak sapi potong selama 1 (satu) tahun berkisar antara Rp 3.000.000 sampai dengan Rp. 47.500.000. Dengan rataan sebesar Rp. 9.647.826,087/tahun/peternak. Dari nilai rata-rata pendapatan keluarga dari usaha ternak sapi potong ini dapat menggambarkan bahwa responden kurang termotivasi untuk melakukan pengembangan usaha ternak sapinya, mereka belum melihat dengan baik bahwa ternak sapi 
potong yang mereka usahakan dapat mendatangkan pendapatan yang lebih besar apabila dilakukan dengan serius.

Analisis B/C Ratio digunakan dalam suatu usaha untuk mengetahui layak atau tidak usaha itu untuk dilanjutkan ke periode berikutnya atau sebaliknya usaha tersebut dihentikan karena kurang layak. Dari tabel diatas diperoleh B/C Ratio 1,35. Hal ini menunjukkan bahwa usaha ternak rakyat tersebut layak untuk dilanjutkan. Suatu usaha dapat dikatakan memberikan keuntungan bila nilai $\mathrm{B} / \mathrm{C}$ ratio diatas $1(>1)$. Semakin besar nilai $\mathrm{B} / \mathrm{C}$ ratio maka semakin efisien usaha tersebut dan sebaliknya semakin kecil nilai $\mathrm{B} / \mathrm{C}$ ratio maka semakin tidak efisien usaha tersebut.

\section{Pengaruh variabel penelitian terhadap pendapatan peternak sapi potong}

Hasil pengujian faktor-faktor yang mempengaruhi pendapatan peternak sapi potong di Kecamatan Siempat Nempu Hulu Kabupaten Dairi dapat di lihat pada Tabel 4.

Tabel 3. Analisis varian pendapatan dan hasil penduga variabel

\begin{tabular}{lcccc}
\hline Sumber & Derajat Bebas & F tabel & F hitung & $\begin{array}{c}\text { Tingkat } \\
\text { Signifikansi }\end{array}$ \\
\hline Regresi & 6 & 2,25 & 5945.220 & $0.000^{\mathrm{a}}$ \\
Residual & 62 & & & \\
\hline Total & 68 & & & \\
\hline
\end{tabular}

Tabel 4. Analisis regresi linier berganda pengaruh pengalaman beternak, tingkat pendidikan dan umur peternak terhadap pendapatan peternak sapi potong

\begin{tabular}{lllcl}
\hline Variabel & Koefisien Regresi & Std. Error & t-hitung & Signifikan \\
\hline Konstanta & 1111752.019 & 381102.418 & 2.917 & 0.005 \\
$\mathrm{X}_{1}$ & 1990426.502 & 16995.448 & 117.115 & 0,000 \\
$\mathrm{X}_{2}$ & -10573.771 & 4701.444 & -2.249 & 0.028 \\
$\mathrm{X}_{3}$ & 125201.236 & 26074.307 & 4.802 & 0.000 \\
$\mathrm{X}_{4}$ & 1124.790 & 11102.122 & 0.101 & 0.920 \\
$\mathrm{X}_{5}$ & -27503.449 & 23994.457 & -1.146 & 0.256 \\
$\mathrm{R}$ square & 0.998 & & & \\
Regresion & 4643641103322872.000 & & & \\
Residual & 8071070590171.503 & & & \\
F-tabel $(\alpha=0,05)$ & 2,25 & & & \\
T-tabel $(\alpha=0,05)$ & 2,00 & & &
\end{tabular}




\section{Keterangan}

a. Predictors : (constant), motivasi beternak, jumlah tanggungan keluarga, pengalaman beternak, umur peternak, tingkat pendidikan, skala usaha

b. Dependent Variabel : Pendapatan Peternak

Pengujian terhadap faktor-faktor yang mempengaruhi pendapatan peternak sapi potong di Kecamatan Siempat Nempu Hulu Kabupaten Dairi digunakan analisis regresi linier berganda, dimana yang menjadi variabel bebas (independent) adalah skala usaha $\left(\mathrm{X}_{1}\right)$, umur peternak $\left(\mathrm{X}_{2}\right)$, tingkat pendidikan $\left(\mathrm{X}_{3}\right)$, lama beternak $\left(\mathrm{X}_{4}\right)$ dan jumlah tanggungan keluarga $\left(\mathrm{X}_{5}\right)$ sedangkan yang menjadi variabel terikat/tidak bebas (dependent) adalah pendapatan (Y).

Berdasarkan hasil yang telah diperoleh, maka untuk melihat faktor-faktor yang mempengaruhi pendapatan dengan menggunakan Model Pendekatan Teknik Ekonometri dengan menggunakan analisis regresi linear berganda alat bantu Software Statistical Package for Sosial Sciences (SPSS 16) dapat dilihat pada Tabel 4.

Berdasarkan Tabel 4 di atas di peroleh persamaan sebagai berikut:

$\hat{\mathrm{Y}}=1.111 .752,019+1.990 .426,502 \mathrm{X}_{1}-10.573,771 \mathrm{X}_{2}+125.201,236 \mathrm{X}_{3}+1.124,790 \mathrm{X}_{4}-$ $27503.449 \mathrm{X}_{5}+\mu$

\section{Keterangan:}

$\hat{\mathrm{Y}} \quad$ : Pendapatan peternak sapi potong (baca : $\mathrm{Y}$ topi)

$\mathrm{X}_{1} \quad$ : Skala usaha (jumlah ternak sapi) dalam Satuan Ternak (ST)

$\mathrm{X}_{2} \quad$ : Umur peternak (tahun)

$\mathrm{X}_{3} \quad$ : Tingkat pendidikan (tahun)

$\mathrm{X}_{4} \quad$ : Lama beternak ( tahun)

$\mathrm{X}_{5} \quad$ :Jumlah tanggungan keluarga (orang)

$\mu \quad$ : Variabel yang tidak di teliti

Berdasarkan hasil regresi di atas dapat diketahui:

1. Nilai Konstanta/Intersept adalah sebesar 1.111.752,019. Artinya apabila variabel bebas yaitu, skala usaha, umur peternak, tingkat pendidikan,lama beternak dan jumlah tanggungan keluarga tidak ada maka peternak sapi potong tetap akan menerima pendapatan sebesar nilai konstanta yaitu Rp 1.111.752,019/tahun.

2. R Square bernilai 0,998 artinya bahwa semua variabel bebas skala usaha ternak (jumlah ternak),umur peternak, tingkat pendidikan, lama beternak dan jumlah tanggungan keluarga 
mempengaruhi variabel terikat sebesar 99,8\% dan selebihnya yaitu sebesar 0,2\% dijelaskan oleh variabel lain $(\mu)$ yang tidak diteliti dalam penelitian ini.

3. Secara serempak nilai F-hitung $(5.945,220)$ lebih besar daripada F-tabel $(2,79)$. Hal ini menunjukkan bahwa secara serempak semua variabel tersebut yaitu skala usaha, umur peternak, tingkat pendidikan, lama beternak dan jumlah tanggungan keluarga berpengaruh secara nyata terhadap pendapatan peternak sapi potong dengan taraf signifikansi $0.000^{\mathrm{a}}$ dan pada taraf kepercayaan $95 \%$.

4. Secara parsial nilai t-hitung variabel yang mempengaruhi adalah variabel jumlah ternak (skala usaha) 117,115 variabel umur peternak $(-2,249)$ variabel tingkat pendidikan $(4,802)$, variabel lama peternak ( 0,101$)$, variabel jumlah tanggungan keluarga $(-1,146)$.

a. Variabel jumlah ternak sapi berpengaruh nyata terhadap pendapatan peternak sapi potong, jika diukur pada tingkat kepercayaan 95\% yang ditunjukkan oleh nilai t-hitung $\left(\mathrm{X}_{1}\right)$ sebesar 117,115 lebih besar dari t-tabel $(\alpha=0.05)$ yakni sebesar 2,00 .

Hal ini menunjukkan bahwa semakin banyak ternak yang dipelihara maka akan semakin besar pula pendapatan yang akan diperoleh peternak sapi potong. Menurut Soekartawi (1995), bahwa pendapatan usaha ternak kerbau sangat dipengaruhi oleh banyaknya ternak yang dijual oleh peternak itu sendiri sehingga semakin banyak jumlah ternak kerbatu maka semakin tinggi pendapatan bersih yang diperoleh.

b. Variabel umur peternak tidak berpengaruh nyata terhadap pendapatan ternak sapi potong, jika diukur pada tingkat kepercayaan 95\% yang di tunjukkan oleh nilai t-hitung $\left(\mathrm{X}_{2}\right)$ sebesar $-2,249$ lebih kecil dari t-tabel $(\alpha=0,05)$ yakni sebesar 2,00 variabel ini bernilai negatif karena di sebabkan kriteria umur peternak tidak mendorong peternak dalam mengembangkan usaha ternak sapi potong di Kecamatan Siempat Nempu Hulu. Faktor umur biasanya lebih di identikkan dengan produktifitas kerja jika seseorang masih tergolong usaha produktif ada kecenderungan produktifitasnya juga tinggi. Chamdi (2003), menge-mukakan semakin muda usia peternak (usia produktif 20-45 tahun) umumnya rasa keingin tahuan terhadap sesuatu semakin tinggi dan minat untuk mengadopsi terhadap introduksi teknologi semakin tinggi.

c. Variabel tingkat pendidikan berpengaruh nyata terhadap pendapatan peternak sapi potong, jika diukur pada tingkat kepercayaan 95\% yang ditunjukkan oleh nilai t-hitung $\left(\mathrm{X}_{3}\right)$ sebesar 4.802 lebih kecil dari nilai t-tabel $(\alpha=0,05)$ yakni sebesar 2,00. Hal ini menunjukkan 
bahwa pendidikan berpengaruh nyata terhadap pendapatan, ini dikarenakan usaha di daerah penelitian bervariasi dan memiliki jenjang jabatan. Winarno (1985), menyatakan bahwa pendidikan sedikit banyak mempunyai peranan penting terhadap produktivitas peternak dalam mengelola ternaknya. Hal ini menunjukkan bahwa semakin tinggi pendidikan peternak maka semakin tinggi daya serap dan pola pikir terhadap ilmu pengetahuan dan teknologi, sebaliknya semakin rendah tingkat pendidikan maka daya serap dan pola pikir terhadap ilmu pengetahuan dan teknologi juga semakin rendah sehingga sulit untuk mengikuti perkembangan teknologi.

d. Variabel lama beternak tidak berpengaruh nyata terhadap pendapatan peternak sapi potong, jika diukur pada tingkat kepercayaan 95\% yang ditunjukkan oleh nilai t-hitung $\left(\mathrm{X}_{3}\right)$ sebesar 0,101 lebih kecil dari nilai t-tabel $(\alpha=0,05)$ yakni sebesar 2,00. Berdasarkan tingkat pengalaman peternak, hasil penelitian menunjukkan bahwa sebagian besar peternak memiliki pengalaman (lama) beternak diatas 5 tahun $(62,32 \%)$ dari total responden dan sebanyak 37,68\% yang pengalamannya dalam beternak lebih dibawah 5 tahun, dengan ratarata pengalaman (lama) beternak seluruhnya 7,1 tahun. Umumnya pengalaman (lama) beternak diperoleh dari orang tuanya secara turun-temurun. Pengalaman beternak didaerah penelitian cukup tinggi, hal ini seharusnya dapat memberikan pengaruh yang nyata tehadap pendapatan, namun pada kenyataannya tidak memberi pengaruh yang nyata karena masyarakat didaerah tersebut lebih cenderung menggunakan metode lama secara tradisional dari pada menerapkan inovasi baru dari luar.

e. Variabel jumlah tanggungan keluarga tidak berpengaruh nyata terhadap pendapatan peternak sapi potong, jika diukur pada tingkat kepercayaan 95\% yang ditunjukkan oleh thitung $\left(\mathrm{X}_{5}\right)$ sebesar $(-1,146)$ lebih kecil dari t-tabel $(\alpha=0.05)$ yakni sebesar 2,00 hal ini menunjukkan bahwa tanggungan anak dalam keluarga peternak tidak dapat memberikan dorongan positif terhadap peningkatan pendapatan peternak.

Arti dari nilai persamaan berikut adalah:

$$
\begin{aligned}
\hat{Y}= & 1.111 .752,019+1.990 .426,502 X_{1}-10.573,771 X_{2}+125.201,236 X_{3} \\
& 1.124,790 X_{4}-27.503,449 X_{5}+\mu
\end{aligned}
$$


Berdasarkan model persamaan di atas dapat diinterpresikan bahwa:

a. Apabila variabel bebas jumlah ternak $\left(\mathrm{X}_{1}\right)$ mengalami kenaikan sebesar $1 \mathrm{ST}$, maka akan terjadi kenaikan pendapatan (Y) sebesar Rp 1.990.426,502

b. Apabila variabel bebas umur peternak $\left(\mathrm{X}_{2}\right)$ mengalami peningkatan sebesar 1 tahun, maka akan terjadi penurunan pendapatan (Y) sebesar Rp 10.573,771

c. Apabila variabel bebas tingkat pendidikan $\left(\mathrm{X}_{\mathbf{3}}\right)$ mengalami kenaikan sebesar 1 tingkat, maka akan terjadi kenaikan pendapatan peternak (Y) sebesar Rp 125.201,236

d. Apabila variabel bebas lama beternak $\left(\mathrm{X}_{4}\right)$ mengalami peningkatan sebesar 1 tahun, maka akan terjadi peningkatan pendapatan peternak (Y) sebesar Rp 1.124,790.

e. Apabila variabel bebas jumlah tanggungan keluarga $\left(\mathrm{X}_{5}\right)$ mengalami kenaikan sebesar 1 orang, maka akan terjadi penurunan pendapatan peternak (Y) sebesar Rp 27.503,449.

f. Apabila varibel $X_{1}, X_{2}, X_{3}, X_{4}$ dan $X_{5}$ yang di analisis diabaikan( tidak melakukan aktivitas), maka peternak sapi potong akan tetap menerima pendapatan sebesar Rp 1.111.752,019/tahun atau Rp 92.646,001/bulan.

\section{KESIMPULAN}

Skala usaha dan tingkat pendidikan peternak memberikan pengaruh positif dalam meningkatkan pendapatan peternak sedangkan umur peternak, lama beternak dan jumlah tanggungan keluarga tidak memberikan peningkatan pendapatan peternak sapi potong di Kecamatan Siempat Nempu Hulu, Kabupaten Dairi.

\section{DAFTAR PUSTAKA}

Azis, M. A., 1993. Agroindustri Sapi Potong, Prospek pengembangan pada PJPT II. Bangkit. Jakarta.

Badan Pusat Statistik Kabupaten Dairi, 2013.

Chamdi, A. N., 2003. Kajian Profil Sosial Ekonomi Usaha Kambing Di Kecamatan Kradenan Kabupaten Grobongan. Prosiding Seminar Nasional Teknologi Peternakan dan Veteriner. Bogor 29-30 September 2003. Bogor: Puslitbang Peternakan Departemen Pertanian. 
Djalal, N. dan H. Usman. 2002. Penggunaan Teknik Ekonometri. Edisi I. Cetakan I. Raja Grafindo Persada. Jakarta.

Fathoni, A. H., 2004. Manajemen Sumber Daya Manusia. Rhineka Cipta. Jakarta.

Santoso., 1979. Analisis Usaha Ternak Sapi Perah di daerah Jawa Tengah dan Jawa Timur. Buletin LPP. No. 23. Bogor.

Soekartawi, 1995. Analisis Usahatani. Universitas Indonesia. Jakarta.

Sosroamidjojo, S. dan Soeradji. 1990. Peternakan Umum. Yasaguna. Jakarta.

Widjaja, K., 1999. Analisis Pengambilan Keputusan Usaha Produksi Peternakan. Lembaga Pengabdian Kepada Masyarakat. Institut Pertanian Bogor. Bogor.

Winarno. 1985. Analisis Manajemen dan Pemasaran Susu Usaha Peternakan Sapi Perah di Kota Madya Yogyakarta. Tesis S-2. Fakultas Peternakan Universitas Gadjah Mada. Yogyakarta.

Winartha, I. M. 2006. Metodologi Penelitian Sosial Ekonomi. Andi. Yogyakarta. 